\title{
Effect of Zinc Heavy Metal on Stress-Related Genes in Tomato (Solanum lycopericum L.) Plants
}

\author{
Ekrem Bolukbasi*1, 2, Mehmet Karakas ${ }^{3}$
}

\author{
${ }^{1}$ Amasya University, Suluova Vocational School, Department of Environmental Protection and Monitoring, Amasya, TURKEY \\ ${ }^{2}$ Amasy a University, Central Research Laboratory, Amasya, TURKEY \\ ${ }^{3}$ Ankara University, Science Faculty, Department of Biology, Ankara, TURKEY \\ *ekrem2066@hotmail.com
}

\begin{abstract}
Heavy metal pollution is a major environmental problem all over the world. It is known that high concentration of heavy metals in soils and waters cause genotoxicity and damage to most of the functional biomolecules. The aim of this study was to determine the molecularchanges in tomato (Solanum lycopericum L.) genome under heavy metal of zinc stress. Zinc is a microelement which should be taken in very less amounts by plants, animals and humans. In plants, zinc in low concentration is essential for root and stem elongation, RNA levels, the cell's ribosome content and protein formation mechanism. But at high concentrations, it is toxic for plants like cadmium, lead and copper.In this current study, the molecular response of tomato (Solanum lycopericum L.) plants to zinc stress was examined by transcript accumulation analysis of two stress-related genes: (i) MT2 (metallothionein) gene, coding for a metal-binding protein and (ii) GR1 (glutathionreductase) gene, a marker of enzymatic ROS scavenging mechanism. A quantitative Real-Time PCR experiment was performed with MT2 and GR1 genes using RNA isolated from tomato roots or shoots treated for 24 hith zinc at concentrations ranging from 20 to 1280 ppm. Results showed that the genes were over-expressed in zinc-stressed tomato. The highest relative fold change value was measured on GR1 for both root and shoot indicating the activation of the oxidative stress enzyme to tolerate zinc stress.
\end{abstract}

Keywords-Zinc Heavy Metal, Tomato Plants, MT2, GR1.

\section{INTRODUCTION}

Crop plants such as tomato are frequently exposed to avariety of abiotic stresses including drought, salinity and heavy metal pollutions. Several industrial activities, urban waste, spraying and fertilization held in agriculture and uses of heavy metal-containing pesticides are some of the sources of heavy metal pollution. These pollutants causes decrease in the quality of agricultural products [1-3]. Heavy metal toxicity effects biological molecules, for example, when metals binds to $\mathrm{S}$ group, blocks the active site of enzyme, and may cause conformational changes in enzymes, disrupts the cellular homeostasis and cause oxidative damage by generating reactive oxygen species (ROS) such as singlet oxygen, hydrogen peroxide, hydroxyl radical which cause lipid peroxidation, membrane defects and unstability of enzymes in higher plants [4-7]. Zinc ( $\mathrm{Zn})$ is indispensable metal for normal growth. Zinc is a microelement which should be taken in very less amounts by plants, animals and humans. In plants, zinc in low concentration is essential for root and stem elongation, RNA levels, the cell's ribosome content and protein formation mechanism. But at high concentrations, it is toxic for plants like cadmium, lead and copper $[8,9]$. The toxic effect of zinc cause damages to the cell division and it especially gives damages to the cell nucleus of meristematic stem cellas cell division. Also genetic variations in sensitivity to $\mathrm{Zn}$ toxicity has been mapped in plants $[10,12]$. Zinc $(\mathrm{Zn})$ is a potential environmental toxicant for plants under excessive conditions. In this study, to understand the molecular response of tomato (Solanum lycopericum L.) plants to high zinc stress was examined by transcript accumulation analysis of two stress-related genes: (i) MT2 (metallothionein) gene, coding for a metal-binding protein and (ii) GRl (glutathionreductase) gene, a marker of enzymatic ROS scavenging mechanism [13, 14].

So, in our study we demonstrated the activation of these genes under $\mathrm{Zn}$ treatment in nutrient solution. In addition this study reports that the activation of these genes could serve as a possible additional $\mathrm{Zn}$-tolerance mechanis $\mathrm{m}$ to cope with toxic level of $\mathrm{Zn}$ in tomatoes. 


\section{MATERIAL AND METHODS}

\section{Plant growth and Zinc treatment}

Tomato plants were grown in seedling trays were filled with sterilized perlite. Tomato seeds were germinated and grown hydroponically in pots containing $0.2 \mathrm{~L}$ of modified 1/10 Hoagland's solution. Tomato plants with three biological replicates, each consis ting of one pot with ten plants were grown in a controlled environmental growth chamber with light of $250 \mathrm{mmol} \mathrm{m}^{-2} \mathrm{~s}^{-1}$ photosynthetic photon flux at $23-26^{\circ} \mathrm{C}$, and with $50-60 \%$ relative humidity.

After 21 days of growth with hoagland solution containing macronutriens and micronutrients, seedlings were exposed to $20,40,80,160,320,640,1280 \mathrm{ppm}$ zinc solution $\left(\mathrm{ZnSO}_{4} \cdot 6 \mathrm{H}_{2} \mathrm{O}\right)$ for $24 \mathrm{~h}$. Roots and shoots were harvested and stored at $-80^{\circ} \mathrm{C}$ until RNA is olation.

\section{RNA isolation and first strand cDNA synthesis}

Total RNA of all root and shoot samples were extracted by using Trizol RNA extraction protocol followed by RNeasy mini kit (Qiagen, Cat no: 74104) to cleanup [15]. The quantity and quality of RNA was determined by NanoDrop Lite Spectrophotometer and also confirmed by gel electrophoresis which contains $1.5 \%$ agarose gel and formaldehyde. Extracted RNAs were stored at $-80{ }^{\circ} \mathrm{C}$.

\section{First strand cDNA synthesis}

A two-step procedure was used for real-time reverse transcriptase-polymerase chain reaction (RT-PCR). Reverse transcription reactions were performed with $2 \mu \mathrm{g}$ of RNA, $2.5 \mu \mathrm{M}$ Anchoredoligo(dT)18, 1X Transcriptor High Fidelity Reverse Transcriptase Reaction Buffer, 20 U Protector Rnase Inhibitor, $1 \mathrm{mM}$ deoxynucleotide mix and $10 \mathrm{U}$ Transcriptor highfidelity reverse transcriptase using the high fidelity cDNA synthesis kit (Roche). The quantity and quality of cDNA was determined by NanoDrop Lite Spectrophotometer.

\section{qRT-PCR analysis of $G R 1$ and $M T 2$ genes}

Real-time PCRwas performed using Light Cycler ${ }^{\circledR}$ Nano System (Roche). Gene-specific qRT-PCR primers (Table 1) for $G R 1$ and $M T 2$ genes and actin $(A C T)$ were designed using Primer 3 software [16] based on the sequence information of tomato genes available in the databank (http://www.ncbi.nlm.nih.gov/). Amplifications of the PCR product were monitored via SYBR Green I dye.

PCR conditions consisted of a $95{ }^{\circ} \mathrm{C}$ for $10 \mathrm{~min}, 40$ cycles of $95{ }^{\circ} \mathrm{C}$ for $7 \mathrm{~s}, 58-62{ }^{\circ} \mathrm{C}$ for $15 \mathrm{~s}, 72{ }^{\circ} \mathrm{C}$ for $10 \mathrm{~s}$ and a melting analysis of 52 to $95{ }^{\circ} \mathrm{C}$ with an increasing temperature $0.5{ }^{\circ} \mathrm{C} \quad \mathrm{min}^{-1}$. The qRT-PCR analysis contained three biological replicates, consisting of three technical replicates.

Table 1. Sequences, melting temperatures of primers and accession numbers of genes used in qRT-PCR

\begin{tabular}{|c|c|c|c|c|}
\hline Gene & & Sequence $\left(5^{\prime}-3^{\prime}\right)$ & $\begin{array}{l}\text { Tm } \\
\left({ }^{\circ} \mathbf{C}\right)\end{array}$ & $\begin{array}{l}\text { Accessio } \\
\text { n no. }\end{array}$ \\
\hline$M T-$ & Forward & GCTGTGGATCTAGCTGCAAGTGCG & 60 & EU88431 \\
\hline 2 & Reverse & AAGGGTTGCACTTGCAGTCAGATC & & 0 \\
\hline GR-1 & $\begin{array}{l}\text { Forward } \\
\text { Reverse }\end{array}$ & $\begin{array}{l}\text { CGTGCTGTGATACTTGGTGG } \\
\text { TCGTGCAAGGATGCATAGTG }\end{array}$ & 60 & FJ265823 \\
\hline$A C T$ & $\begin{array}{l}\text { Forward } \\
\text { Reverse }\end{array}$ & $\begin{array}{l}\text { GGGATGGAGAAGTTTGGTGGTGG } \\
\text { CTTCGACCAAGGGATGGTGTAGC }\end{array}$ & 60 & $\begin{array}{c}\text { EU88430 } \\
9\end{array}$ \\
\hline
\end{tabular}

\section{Statistical analysis}

The abundance of target genetranscripts was normalized to $A C T$ and set relative to the $2^{-\triangle \Delta C T}$ method [17]. Changes in relative expression levels (REL) of the gene were checked for statistical significance according to one way ANOVA. $\mathrm{P}<0.05$ was considered to be statistically significant.

\section{RESULTS AND DISCUSSION}

One of the effects of toxins is to prevent the root and body growth. The accumulation of heavy metals in plant causes negative effects on roots, stems and germination of seeds; when it is exposed to the increasing concentrations of heavy metals [18]. Similarly, as expected in tomato plants, the findings of this study on the length of tomato seedlings' roots and stems are similar with the related literature.

MTs protect plants from metal stresses. High transcription rate of MTs was particularly shown in metallophyte tolerant plant varieties [7, 14]. They have the ability to bind both physiological (such as zinc, copper, and selenium) and xenobiotic (such as cadmium, mercury, silver, and arsenic) heavy metals through their cysteine residue thiol groups. Also, MTs were proposed to function in both metal chaperoning and scavenging of ROS [19]. Studies showed that Arsenic and cadmium stress induces metalloprotein expression and accumulation [20].

GR is a potential enzyme of the ASH-GSH cycle and plays anessential role in the defense system against ROS by sustaining the reduced status of GSH [21]. It plays a crucial role in determining the tolerance of a plant under various types of stress [22]. It has recently been observed that the GR activity increases in the presence of $\mathrm{Cd}$ in various plants [21].

In this study, the tomato seedlings were subjected to Zinc for 24 hour. By referring to the several studies it was 
decided that $24 \mathrm{~h}$ is enough period to trigger to the early stress response.

The expression levels of the MT2, GRI and ACT gene at mRNA level were analyzed in, tomato samples by Realtime PCR (Light CyclerNano, Roche) and the results were summarized in Figure-1 and Figure-2. MT2 and GR1 gene transcript levels were calculated in tomato samples exposed to various concentration of zinc solution. To avoid error, real-time RT-PCR is typically normalized with $A C T$ as an housekeeping and internal control gene and also with the control treatment samples. To evaluate the stability of the results, MT2, GRland ACT transcript levels of all samples were measured three times for each time period.

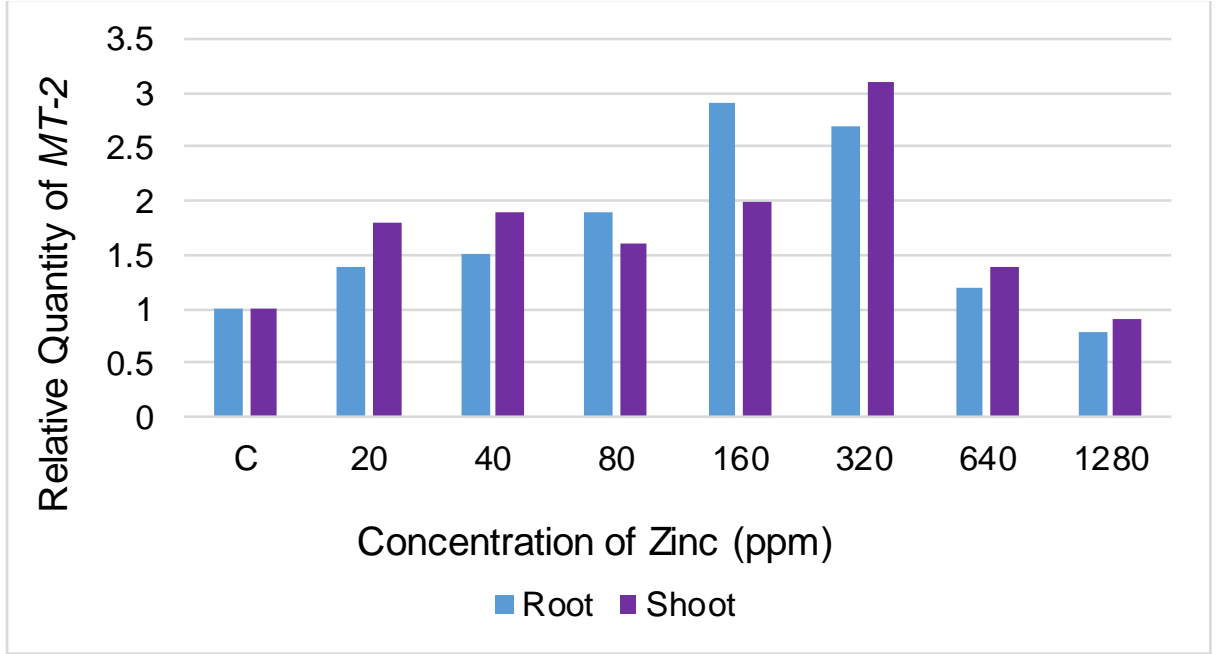

Fig.1: Metallothionein (MT) gene expression profile of root and shoot inthe tomato samples exposed to different concentration of zinc solution.

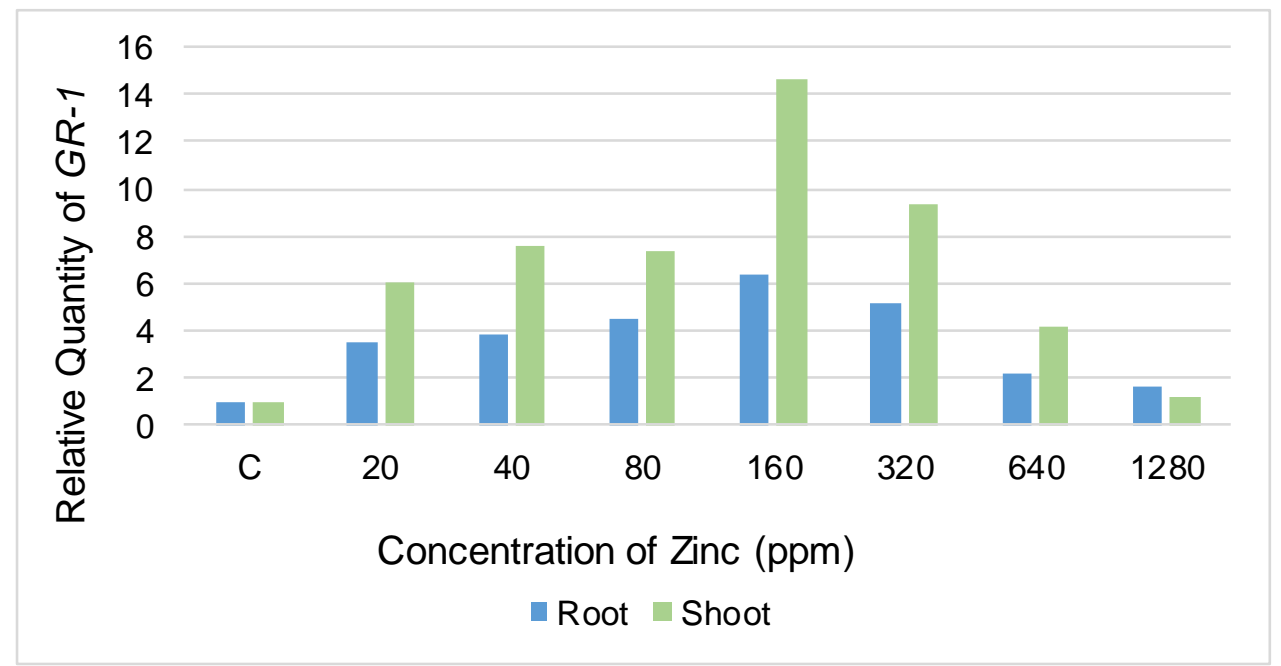

Fig.2: Glutathion reductase (GR) gene expression profile of root and shoot in the tomato samples exposed to different concentration of zinc solution.

In this study, the GRI accumulation was significantly observable under zinc stress for both roots and shoots $(\mathrm{P}<0.01)$. The highest relative fold change value was measured on GRI for both root and shoot. In roots, the abundance of transcript level reached to 6.4 and 5.2-fold increase at concentrations 160 and 320ppm, respectively [Figure-3, $(\mathrm{P}<0.01)]$. 


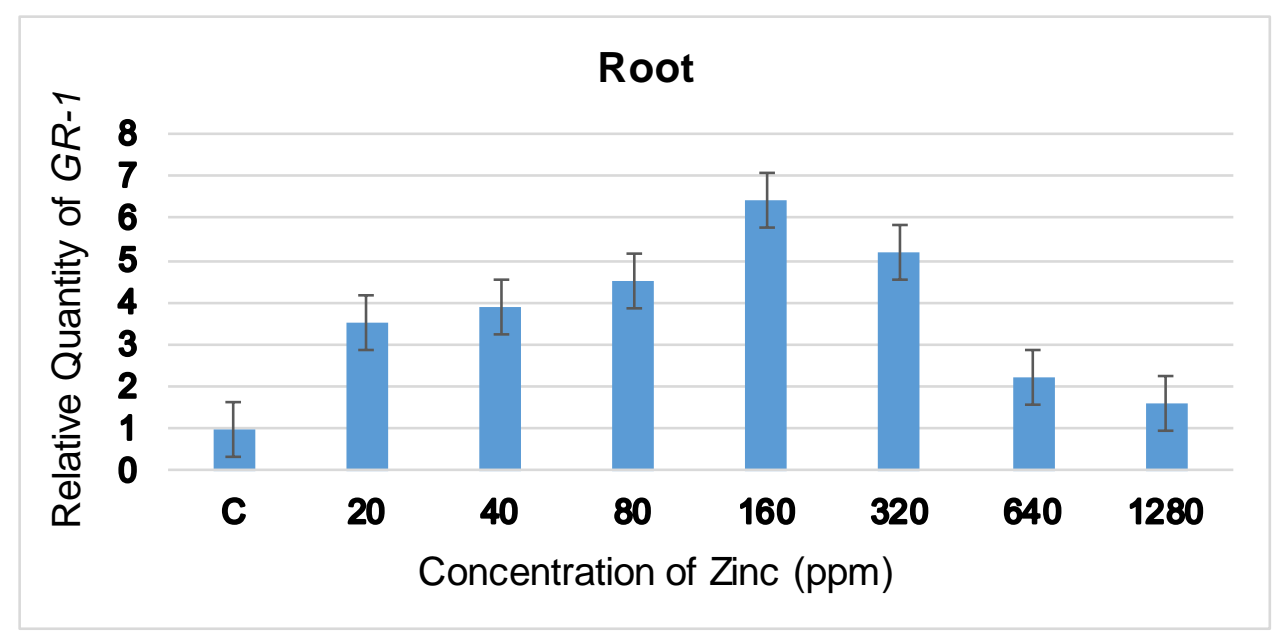

Fig.3: Glutathion reductase (GR) gene expression profile of root in the tomato samples exposed to different concentration of zinc solution.

In shoots the abundance of transcript level reached to 14.6 -fold increase at $160 \mathrm{ppm}$ concentration and 9.4-fold increase at concentration of 320ppm [Figure-4, $(\mathrm{P}<0.01)$ ].

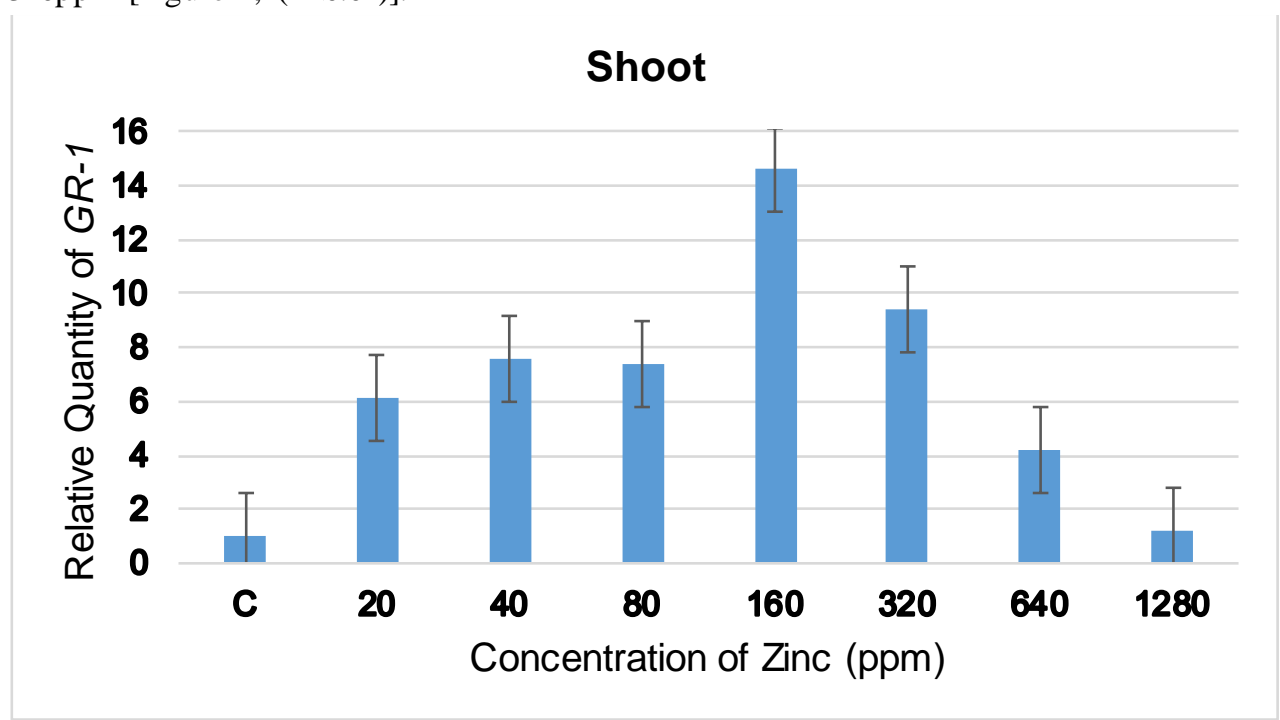

Fig.4: Glutathion reductase (GR) gene expression profile of shoot in the tomato samples exposed to different concentration of zinc solution.

After the concentration of $160 \mathrm{ppm}$, the abundance of GR1 dramatically decreases nearly down to the same as in the control group for both root and shoot, indicating that the resistance mechanism does not allow any protection for the amelioration of the zinc stress by using the GR pathway, due to possible cellular damage. Similar results were observed in zinc-treated tomato root and shoots that of MT2 accumulations was apparent. MT2 accumulation was significantly observable under zinc stress for both roots and shoots $(\mathrm{P}<0.01)$.

In roots, the abundance of transcript level reached to 2,9 and 2,7-fold increase at concentrations 160 and 320 ppm, respectively [Figure-5, $(\mathrm{P}<0.05)$ ]. 


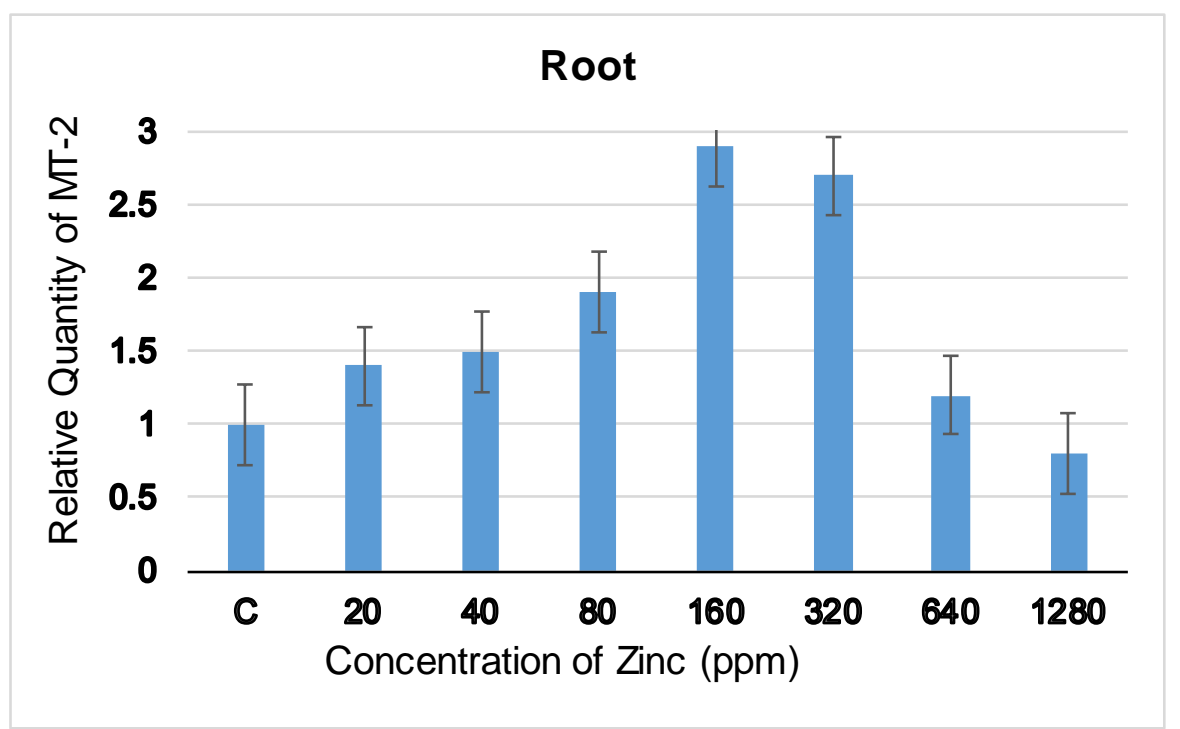

Fig.5: Metallothionein (MT) gene expression profile of root in the tomato samples exposed to different concentration of zinc solution.

In shoots the abundance of transcript level reached to 2 and 3.1-fold increase at concentrations 160 and 320 ppm, respectively. These results indicated that metallothionein binding protein-MT2 transcript accumulation may induce the zinctoxicity tolerance in tomato plant [Figure-6, $(\mathrm{P}<0.05)]$.

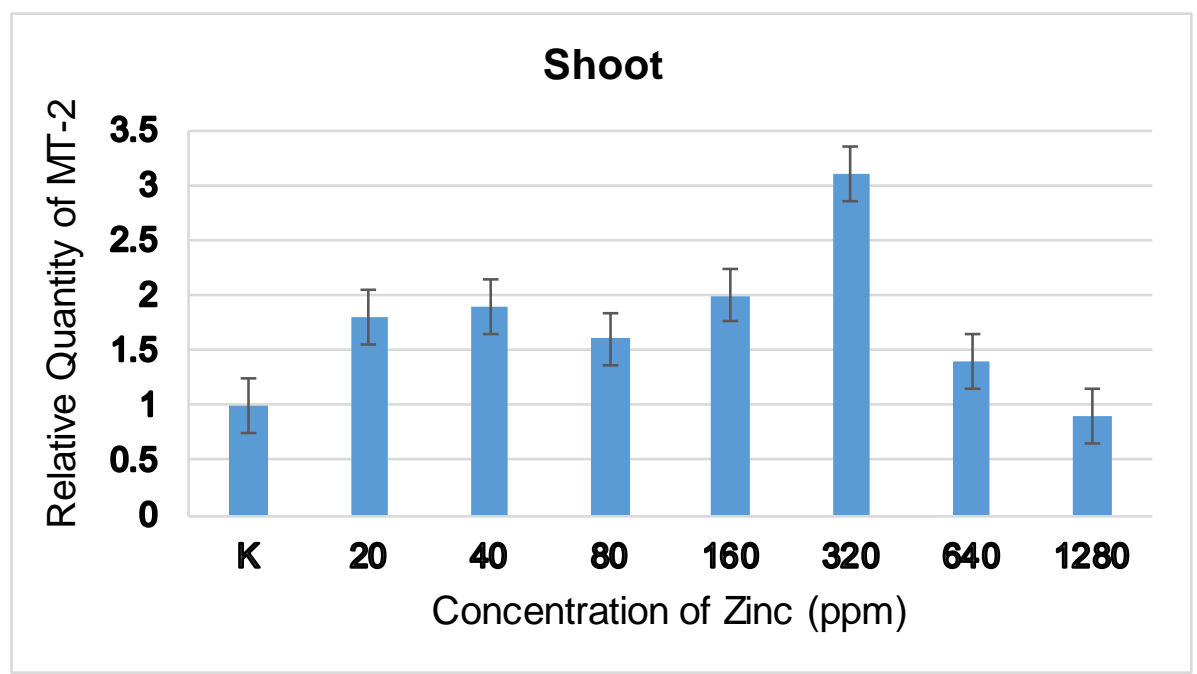

Fig.6: Metallothionein (MT) gene expression profile of shoot in the tomato samples exposed to different concentration of zinc solution.

In conclusion, it was shown here that the activation of $M T 2$ and GRllike protein transcripts under zinc stress. The accumulation of these genes increases at first and then, the curve reflects a descending profile, revealing the disruption of mechanisms which regulates the cellular homeostasis under high zinc levels. The activation of these genes could be a protection mechanism to zinc stress and play important role in the detoxification or tolerance mechanis m.

\section{REFERENCES}

[1] Koc, E., Ustun, A.S. and Arici, Y. 2012. Effect of Different Zinc Concentrations on Total Protein, Hydrogen Peroxide Content and Peroxidase Activity in Pepper (Capsicum annuum L.) Seedlings. Artvin Coruh University, Journal of Forestry Faculty, 13(2), 205-212.

[2] Kirbag, F. and Munzuroglu, O. 2006. Toxic effects of cadmium $\left(\mathrm{Cd}^{+2}\right)$ on metabolism of sunflower (Helianthus annuus L.) seedlings. Acta Agric Scand, Section B - Soil and Plant Sci (3); 56, 224-229.

[3] Soydam A.S., Gokce E., Buyuk I., Aras S. 2012. Characterization of stress induced by copper and zinc on cucumber (Cucumis sativus L.) seedlings by means of 
molecular and population parameters. Mutation Research, 746: 49-55.

[4] Assche, V., Clijters, H., 1990. Effect of metal on enzyme activity on plants, Plant Cell Environ. 13, 195-206.

[5] Conte, C., Mutti, I., Puglisi, P., Ferrarini, A., Regina, G.R.G., Maestri, E., Marmiroli, N., 1998. DNA fingerprint analysis by PCR based method for monitoring the genotoxic effects of heavy metals pollution. Chemosphere 37, 2739-2749.

[6] Savva, D. 1998. Use of the DNA fingerprinting to detect genotoxic effects. Ecotoxicol. Environ. Safely, 41, 103106.

[7] Hall, J.L. 2002. Cellular mechanisms for heavy metal detoxification and tolerance. Journal of Experimental Botany, 53, 1-11.

[8] Bobak, M. 1985. Ultrastructure changes of the nucleus and its components in meristematic root cells of the horse-bean after zinc in toxication. Phy siol Plants, 15, 31-36.

[9] Bolukbasi, E., \& Aras, E.S. 2016. Determination of DNA Methylation Levels with CRED-RA Technique in the Genome of Sunflower Seedlings (Helianthus annuus L.) Subjected to Zinc Stress. International Journal of Environment, Agriculture and Biotechnology, 1(3), 438444.

[10] Mirouze, M. and Paszkowski, J. 2011. Epigenetic contribution to stress adaptation in plants, Current opinion in plant biology, 14; 267-274.

[11] Cervilla, L.M., Blasco, B., Rios, J., Romero, L., Ruiz, J. 2007. Oxidative stress and antioxidants in tomato (Solanum lycopericum) plants subjected to boron toxicity. Ann. Bot. 100, 747-756.

[12] Bolukbasi, E and Aras, E.S. 2018. Determination of Phy siological Biochemical and Molecular Effects of Zinc Stress on the Growth of Sunflower Seedlings (Helianthus annuus L.). International Journal of Environment, Agriculture and Biotechnology (IJEAB), 3(2), 530-536.

[13] Apel, K., Hirt, H. 2004. Reactive oxygen species: metabolism, oxidative stress and signal transduction. Annu. Rev. Plant Biol. 55, 373-399.

[14] Goupila, P., Souguira, D., Ferjanib, E., Faurec, O., Hitmid, A and Ledoigta, G. 2009. Expression of stress-related genes in tomato plants exposed to arsenic and chromiumin nutrient solution. Journal of Plant Physiology 166; 14461452.

[15] Chomczynski, P and K. Mackey. 1995. Short technical reports. Modification of the TRI reagent procedure for isolation of RNA from polysaccharide- and proteoglycanrich sources. Biotechniques, 19, 942-945.

[16] Rozen, S. and H. Skaletsky. 2000. Primer-3 on the www for general users and for biologist programmers. Methods in Molecular Biology, 132: 365-386.

[17] Livak, K.J. and T.D. Schmittgen. 2001. Analysis of relative gene expression data using real-time quantitative PCR and the $2^{-\Delta \triangle C T}$ method. Methods, 25: 402-408.

[18] Zengin, F.K. and Munzuroğlu, O. 2004. Effect of lead $\left(\mathrm{Pb}^{++}\right)$and copper $\left(\mathrm{Cu}^{++}\right)$on the growth of root, shoot and leaf of bean (Phaseolus vulgaris L.) seedlings. G. Ü. Fen Bilimleri Dergisi, 17(3); 1-10.

[19] Wang, L., Yang, L., Yang, F., Li, X., Song, Y., Wang, X., $\mathrm{Hu}, \mathrm{X}$., 2010. Involvements of $\mathrm{H}_{2} \mathrm{O}_{2}$ and metallothionein in NO-mediated tomato tolerance to copper toxicity. J. Plant Physiol. 167, 1298-1306.

[20] Goupil, P., Souguir, D., Ferjani, E., Faure, O., Hitmi, A., Ledoigt, G., 2009. Expression of stress-related genes in tomato plants exposed to arsenic and chromium in nutrient solution. J. Plant Physiol. 166, 1446-1452.

[21] Gill, S.S., Tuteja, N., 2010. Reactive oxy gen species and antioxidant machinery in abiotic stress tolerance in crop plants. Plant Phy siol. Biochem. 48, 909-930.

[22] Gebretsadkan, G., (2018. Evaluating The Effect of Integrated Use of Farm Yard Manure and Urea on the Socio economic Performance of Tomato (Lycopersiconesculentum Mill) at Tselemti Woreda, North western Tigray, Ethiopia. International Journal of Environment, Agriculture And Biotechnology, 3(3), 748755. doi: 10.22161/ijeab/3.3.5

[23] Chalapathi, R., Reddy, A.R., 2008. Glutathione Reductase: a Putative Redox Regulatory System in Plant Cells. In: Khan, N.A. et al. (Eds.), Sulfur Assimilation and Abiotic Stress in Plants. Springer-Verlag, Berlin, Heidelberg, pp. 111-147. 